\title{
Squashed ball-like dsDNA virus infecting a marine fungoid protist Sicyoidochytrium minutum (Thraustochytriaceae, Labyrinthulomycetes)
}

\author{
Yoshitake Takao ${ }^{1}$, Keizo Nagasaki ${ }^{1}$, Daiske Honda ${ }^{2, *}$ \\ ${ }^{1}$ National Research Institute of Fisheries and Environment of Inland Sea, Fisheries Research Agency, 2-17-5 Maruishi, \\ Hatsukaichi, Hiroshima 739-0452, Japan \\ ${ }^{2}$ Department of Biology, Faculty of Science and Engineering, Konan University, 8-9-1 Okamoto, Higashinada, Kobe 658-8501, \\ Japan
}

ABSTRACT: Thraustochytrids are cosmopolitan osmotrophic or heterotrophic microorganisms that play important roles as decomposers, producers of polyunsaturated fatty acids, and pathogens of mollusks, especially in coastal ecosystems. Sicyoidochytrium minutum DNA virus (SmDNAV), a novel double-stranded DNA (dsDNA) virus infecting a marine eukaryotic decomposer, S. minutum (formerly Ulkenia minuta), was isolated from the estuary of the Shukugawa River, Hyogo Prefecture, Japan in July 2003, and its basic characteristics were examined. The morphology of the virus particles is 'squashed ball-like' (ca. 146 and $112 \mathrm{~nm}$ in length and width, respectively) and lacking a tail, distinctive from any other previously known viruses. Virions are formed in the cytoplasm of host cells, frequently accompanied by the disappearance of the nucleus. The lytic cycle and the burst size were estimated at $<8 \mathrm{~h}$ and $3.6 \times 10^{2}$ to $1.1 \times 10^{3}$ infectious units per host cell, respectively. SmDNAV harbored a single molecule of dsDNA approximately $200 \mathrm{kbp}$ in length. This is the first report of a marine fungoid protist-infecting DNA virus that has been isolated and characterized.

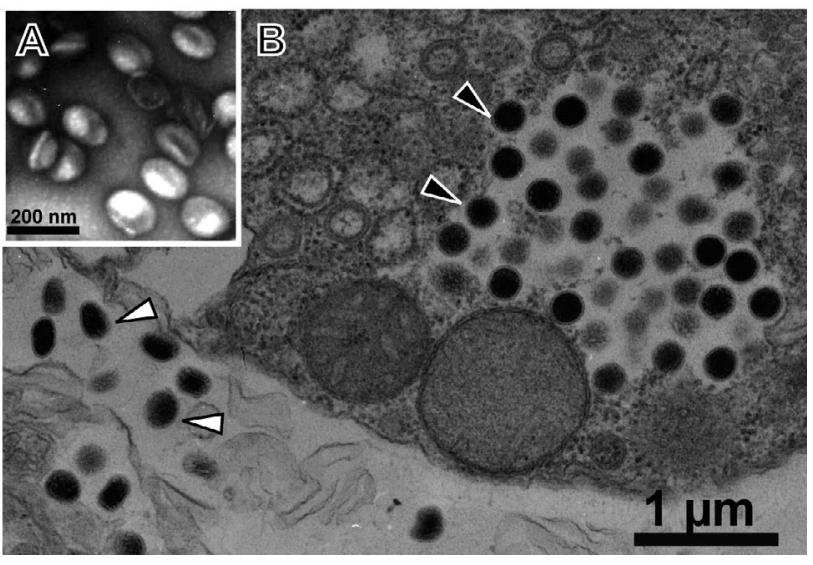

TEM of a novel virus (SmDNAV) infecting a heterotrophic protist Sicyoidochytrium minutum. (A) Negatively stained SmDNAV particles (scale bar $=200 \mathrm{~nm}) ;(B)$ thin section of a SmDNAV-infected cell at $24 \mathrm{~h}$ post inoculation (black arrowheads: intracellular virions; white arrowheads: extracellular virions).

Photo: Yoshitake Takao

and parasites (Porter 1989). Naganuma et al. (1998) estimated the abundance of thraustochytrids in the Seto Inland Sea of Japan, and demonstrated that their biovolume in coastal waters could reach $43 \%$ of the bacterial biovolume. In addition, thraustochytrids are known to produce large amounts of polyunsaturated fatty acids such as docosahexaenoic acid and docosapentaenoic acid (Nakahara et al. 1996), which are important food resources for higher organisms in marine systems (Kimura et al. 1999, Raghukumar 2002). Furthermore, some species of thraustochytrids are pathogens of mollusks, 
such as octopuses and shellfish (Polglase 1980, Ragan et al. 2000). Because of their ubiquitousness and ability to utilize a wide variety of organic substrates their ecological significance in the coastal ecosystems has been highlighted (Raghukumar 2002).

On the other hand, large numbers of viruses and virus-like particles (VLPs) have been discovered in a variety of phytoplankton and bacteria, and they are recognized as important agents in controlling bacterial and algal biomasses (Proctor \& Fuhrman 1990, Brussaard 2004), in nutrient cycling (Wilhelm \& Suttle 1999), and in maintaining biodiversity of bacteria and microalgae (Fuhrman 1999, Brussaard 2004). To date, more than 13 viruses infecting marine eukaryotic microalgae have been isolated and characterized. The majority are large 100 to $200 \mathrm{~nm}$ icosahedral double-stranded DNA (dsDNA) viruses that are included in the family Phycodnaviridae (Wilson et al. 2005) or are considered most likely belonging to this family (Brussaard 2004).

The relationship between colorless protists and their viruses is poorly understood. Nagasaki et al. (1993, 1995) observed VLPs in marine apochlorotic flagellates, and suggested that viral infection might be one of the factors affecting their dynamics. Garza \& Suttle (1995) isolated and characterized a large dsDNA virus infecting a marine heterotrophic nanoflagellate (later shown to be Cafeteria sp.), which also shared some characteristics with those belonging to the family Phycodnaviridae. Recently, an extremely large dsDNA virus (750 nm, 1.2 Mbp) was found infecting amoebae and named Mimivirus, and a genomic analysis was performed (Raoult et al. 2004). Based on phylogenetic analysis of the DNA polymerase amino acid sequence, the Mimivirus formed a sister group with the Family Phycodnaviridae (Iyer et al. 2006). With respect to fungoid protists, Dawe \& Kuhn (1983) succeeded in inducing viruses from Hypochytridiales by thermal treatment; they were icosahedral, $60 \mathrm{~nm}$ in diameter and had a dsDNA genome. In the case of thraustochytrids, Kazama \& Schornstein (1973) discovered herpes-type VLPs in Thraustochytrium sp.; they were roundish, enveloped, $110 \mathrm{~nm}$ in diameter, and predicted to have a DNA genome. However, because the VLPs were not successfully cultured, further studies were not conducted.

Previously, we reported on a novel single-stranded RNA (ssRNA) virus infecting the thraustochytrid Aurantiochytrium sp. NIBH N1-27 (formerly Schizochytrium sp. NIBH N1-27, see Yokoyama \& Honda 2007) and designated the virus as Schizochytrium single-stranded RNA virus (SssRNAV: ca. $25 \mathrm{~nm}$ in diameter, ca. $9 \mathrm{~kb}$ ssRNA genome) (Takao et al. 2005, 2006). The wide distribution range of SssRNAV and its host suggested that they have an ecologically close relationship with each other in coastal areas (Y. Takao et al. unpubl. data).
In the present study, we describe the isolation and fundamental characterization of a novel dsDNA virus infecting Sicyoidochytrium minutum strain NBRC 102975 (MBIC 11071) (formerly Ulkenia minuta, see Yokoyama et al. 2007). To our knowledge, this is the first report describing the biological properties of a DNA virus infecting marine fungoid protists.

\section{MATERIALS AND METHODS}

Microorganism cultures. Strains of thraustochytrids and other microorganisms used in this study are listed in Table 1. All of them are clonal, established by the micropipetting method or an extinction dilution method. Thraustochytrids were grown at $20^{\circ} \mathrm{C}$ in $10 \times$ medium-H (medium- $\mathrm{H}=0.2 \%$ glucose, $0.02 \%$ yeast extract, $0.05 \%$ monosodium glutamate in seawater). Other organisms were grown at $20^{\circ} \mathrm{C}$ in modified SWM-3 (Chen et al. 1969, Imai \& Itoh 1987). For cultivation of phytoplankton, light conditions were set at a 12:12 h light:dark cycle at $55 \mu \mathrm{mol}$ photons $\mathrm{m}^{-2} \mathrm{~s}^{-1}$ with cool white fluorescent illumination.

Isolation of lytic viruses. Surface water was collected in the Shukugawa River estuary, Hyogo Prefecture, Japan, on 29 July 2003. It was filtered through a $0.2 \mu \mathrm{m}$ pore-size filter (Nuclepore) to remove eukaryotic microorganisms and most bacteria. Aliquots $(100 \mu \mathrm{l})$ of the filtrate were inoculated into exponentially growing cultures $(150 \mu \mathrm{l})$ of the thraustochytrid strains shown in Table 1 , and incubated at $20^{\circ} \mathrm{C}$. Cultures inoculated with the filtrates treated at $121^{\circ} \mathrm{C}$ for 15 min served as controls. Test cultures and control cultures were checked by optical microscopy for $14 \mathrm{~d}$ to examine whether cell lysis occurred. An apparent growth inhibition was detected in the Sicyoidochytrium minutum strain NBRC 102975 culture inoculated with the filtrate; in contrast, no lysis was observed in the other strains and control cultures. The lytic agent (pathogen) was then made clonal through 2 cycles of the extinction dilution procedure (Suttle 1993). The lysate in the most diluted well of the second assay was inoculated into a $50 \mathrm{ml}$ fresh culture of S. minutum strain NBRC 102975, and the resultant lysate was filtered through a $0.2 \mu \mathrm{m}$ pore-size filter (Nuclepore). Then, $0.3 \mathrm{ml}$ of the filtrate was mixed with $1 \mathrm{ml}$ of $10 \%$ glycerol in $10 \times$ medium-H and cryopreserved at $-80^{\circ} \mathrm{C}$ as the original pathogen suspension. Serial transfers of a lysed culture to an exponentially growing culture of $S$. minutum strain NBRC 102975 were performed more than twice to verify its transferability. Concentration of the pathogenic agent was estimated by means of the extinction dilution method using the computer program given by Nishihara et al. (1986). 
Table 1. Infection specificities of Sicyoidochytrium minutum DNA virus (SmDNAV) against 22 strains of marine microorganisms. ND: no data; + : lysed $;$-: not lysed

\begin{tabular}{|c|c|c|c|}
\hline Taxon & Strains & Isolation locality & $\begin{array}{l}\text { itivity to } \\
\text { DNAV }\end{array}$ \\
\hline \multicolumn{4}{|c|}{ Kingdom Chromista } \\
\hline \multirow[t]{13}{*}{ Thraustochytriaceae } & Aurantiochytrium sp. NIBH N1-27a & Nakaminato Harbor, Ibaragi, Japan & - \\
\hline & Aurantiochytrium limacinum NIBH SR-21 (IFO 32693)a & Colonia, Yap Island, Micronesia & - \\
\hline & Aurantiochytrium sp. MBIC $11066^{\mathrm{a}}$ & Iriomote Island, Okinawa, Japan & - \\
\hline & Aurantiochytrium sp. NBRC 102976 (MBIC 11072)a & Iriomote Island, Okinawa, Japan & - \\
\hline & Aurantiochytrium sp. NBRC 102614 (SEK 209) $^{\mathrm{a}}$ & Kobe Habor, Hyogo, Japan & - \\
\hline & Schizochytrium sp. NBRC 102615 (SEK 210) $^{\mathrm{a}}$ & Okinawa Island, Okinawa, Japan & - \\
\hline & Schizochytrium sp. SEK 0213 & Iriomote Island, Okinawa, Japan & - \\
\hline & Thraustochytrium aureum ATCC $34304^{\mathrm{a}}$ & Woods Hole, Massachusetts, USA & - \\
\hline & Sicyoidochytrium minutum NBRC 102975 (MBIC 11071) & Iriomote Island, Okinawa, Japan & + \\
\hline & Sicyoidochytrium minutum SEK 0354 & Langkawi Island, Malaysia & + \\
\hline & Parietichytrium sp. SEK 0211 ${ }^{\mathrm{a}}$ & Ishigaki Island, Okinawa, Japan & - \\
\hline & Parietichytrium sp. SEK 0212a & Ishigaki Island, Okinawa, Japan & - \\
\hline & Ulkenia amoeboidea SEK 0214 ${ }^{\mathrm{a}}$ & Hiroshima Bay, Hiroshima, Japan & - \\
\hline \multirow[t]{5}{*}{ Bacillariophyceae } & Chaetoceros sarsginium Ch42 & Ariake Sea, Saga, Japan & - \\
\hline & Rhizosolenia setigera Rs-2 & ND & - \\
\hline & Eucampia zodiacus AR040128 & Ariake Sea, Fukuoka, Japan & - \\
\hline & Coscinodiscus wailesii 021121AR02 & Ariake Sea, Saga, Japan & - \\
\hline & Ditylum brightwelli Dity & ND & - \\
\hline Raphidophyceae & Heterosigma akashiwo H93616 & Hiroshima Bay, Hiroshima, Japan & - \\
\hline \multicolumn{4}{|l|}{ Kingdom Protozoa } \\
\hline \multirow[t]{2}{*}{ Phylum Dinozoa } & Hetrocapsa circularisquama HCLG1 & Gokasyo Bay, Mie, Japan & - \\
\hline & Karenia mikimotoi TK-3 & Tokuyama Bay, Yamaguchi, Japan & - \\
\hline
\end{tabular}

Host range test. The host range of the clonal pathogenic agent was examined by adding $100 \mu \mathrm{l}$ of the original pathogen suspension to each $1 \mathrm{ml}$ culture of the exponentially growing microorganisms listed in Table 1. Each culture was incubated at its appropriate condition mentioned above and observed by optical microscopy. Cultures that were not lysed after $10 \mathrm{~d}$ were regarded as unsuitable hosts for the pathogen.

Growth experiment. In the growth experiments, exponentially growing cultures of the Sicyoidochytrium minutum strain NBRC 102975 were inoculated with the pathogen suspension at an moi (multiplicity of infection) of 6.2 to 6.4. Control cultures, to which an autoclaved $\left(121^{\circ} \mathrm{C}, 15 \mathrm{~min}\right)$ filtrate was added, served for comparison. Aliquots of the cell suspension were sampled every $8 \mathrm{~h}$; then, cell density was estimated by optical microscopy, and the pathogen density was measured by the extinction dilution method (Suttle 1993). Each experiment was run in triplicate.

Chloroform sensitivity assay. In order to measure the effect of organic solvent on virus infectivity, the chloroform sensitivity assay was conducted in duplicate. Equal volumes of virus suspension and chloroform were mixed by voltex for $15 \mathrm{~s}$ and centrifuged at $17500 \times g$ for $5 \mathrm{~min}$. Then, the aqueous phase was extracted, and inoculated to exponentially growing cultures of Sicyoidochytrium minutum. Cultures inoculated with chloroform-treated medium and untreated viral suspension served as negative controls and positive controls, respectively. Each culture was incubated under conditions mentioned above and observed by optical microscopy.

Transmission electron microscopy (TEM). To prepare samples of the pathogen for TEM observation, an exponentially growing culture of Sicyoidochytrium minutum strain NBRC 102975 was inoculated with the pathogen; then, aliquots $(2 \mathrm{ml})$ were sampled at 0,8 , 16 , and $24 \mathrm{~h}$ post inoculation. Each cell suspension was fixed with $5 \%$ glutaraldehyde in an equal volume of $0.2 \mathrm{M}$ sucrose and 0.2 M cacodylate buffer and kept on ice for $2 \mathrm{~h}$. Cells were harvested by centrifugation at $640 \times g$ for $2 \mathrm{~min}$. The pellet was rinsed 3 times with $0.2 \mathrm{M}$ cacodylate buffer and post-fixed with $1 \%$ buffered $\mathrm{OsO}_{4}$ for $1.5 \mathrm{~h}$ on ice. Following the 3 rinses with the buffer, the pellet was dehydrated in a graded ethanol series (30 to $100 \%$ ), infiltrated with propylene oxide, and embedded in Spurr's resin (NISSHIN EM). Thin sections were stained with $1 \%$ uranyl acetate and $3 \%$ lead citrate, and observed at $80 \mathrm{kV}$ using a JEOL JEM-1010 transmission electron microscope. Negatively stained pathogens were also observed by TEM; briefly, the fresh lysate was mounted on a grid (No. 780111630, JEOL DATUM) for $30 \mathrm{~s}$, and excess water 
was removed by filter paper (No. 1, TOYO). Then, $4 \%$ uranyl acetate was mounted on the grid for $10 \mathrm{~s}$ and the excess dye was removed with the filter paper. After drying the grid in a desiccator for $10 \mathrm{~min}$, negatively stained pathogens were observed by TEM at $80 \mathrm{kV}$. Particle diameters were estimated based on the negatively stained images.

Purification of virions and viral genome. Sicyoidochytrium minutum strain NBRC 102975 culture (1.5 l) was inoculated with $2 \mathrm{ml}$ of fresh pathogen suspension and lysed. The lysates were centrifuged at $14000 \times g$ for $15 \mathrm{~min}$ to remove cellular debris. The supernatant was added with polyethylene glycol 6000 (Wako) to set the final concentration at $10 \%$ $(\mathrm{w} / \mathrm{v})$, and stored at $4^{\circ} \mathrm{C}$ overnight. After centrifugation at $3600 \times g$ for $1.5 \mathrm{~h}$, the pellet was suspended in $10 \mathrm{mM}$ phosphate buffer $\left(10 \mathrm{mM} \mathrm{Na}_{2} \mathrm{HPO}_{4}\right.$ and $10 \mathrm{mM}$ $\mathrm{KH}_{2} \mathrm{PO}_{4}$ in distilled water) and again centrifuged at $100000 \times g$ for $2 \mathrm{~h}$. This purification process was repeated twice. The pellet was resuspended in $500 \mu \mathrm{l}$ of distilled water.

The viral genome was extracted by treating the viral suspension with Proteinase $\mathrm{K}\left(1 \mathrm{mg} \mathrm{ml}^{-1}\right.$, Wako Pure Chemical Industries) and sarcosyl (1\%; International Technologies) at $55^{\circ} \mathrm{C}$ for $1.5 \mathrm{~h}$. The aqueous phase was extracted twice with $500 \mu \mathrm{l}$ of P/C/I (phenol: chloroform : isoamyl alcohol $=25: 24: 1$ ). The nucleic acids were precipitated with ethanol, dried and suspended in $50 \mu \mathrm{l}$ of TE buffer (10 mM Tris- $\mathrm{HCl}, 1 \mathrm{mM}$ EDTA, $\mathrm{pH}$ 8.0). To remove the polysaccharide, $750 \mu \mathrm{l}$ of $2 \times \mathrm{CTAB}$ solution $(2 \%$ CTAB, $100 \mathrm{mM}$ Tris- $\mathrm{HCl}[\mathrm{pH} 8.0], 1.4 \mathrm{M}$ $\mathrm{NaCl}, 20 \mathrm{mM}$ EDTA, $0.5 \%$ 2-mercaptoethanol in distilled water) was added to the suspension and incubated at $65^{\circ} \mathrm{C}$ for $1 \mathrm{~h}$. The aqueous phase was extracted twice with $500 \mu \mathrm{l}$ of P/C/I. The nucleic acids were precipitated with ethanol, dried and suspended in $50 \mu \mathrm{l}$ of TE buffer.

Analysis of nucleic acids and proteins. The genome size was estimated by means of PFGE (pulsed-field gel electrophoresis). The $100 \mu \mathrm{l}$ purified virus suspension was mixed with $700 \mu \mathrm{l}$ of $1 \%$ Agarose-LM (Nacalai Tesque), dispensed into plug molds, and solidified. The plugs were punched out of the molds into a small volume of digestion buffer containing $250 \mathrm{mM}$ EDTA, 1\% sodium dodecyl sulfate (SDS) and $1 \mathrm{mg} \mathrm{ml}^{-1}$ Proteinase K (Wako Pure Chemical Industries), and then incubated overnight at $50^{\circ} \mathrm{C}$. The digestion buffer was decanted and the plugs were washed 8 times for $1 \mathrm{~h}$ in TE buffer (stored at $4^{\circ} \mathrm{C}$ ). The plugs were placed in wells of $1.2 \%$ SeaKem Gold agarose (FMC-Bioproducts) in $0.5 \times$ TBE gel buffer $(90 \mathrm{mM}$ Tris-borate, $1 \mathrm{mM}$ EDTA, pH 8.0) and overlaid with molten $0.5 \%$ Agarose-LM. Agarose plugs containing lambdaphage concatemers (Promega) were used as a molec- ular weight standard. The samples were electrophoresed using a Gene Navigator System (Amersham Biosciences) at $180 \mathrm{~V}$ with pulse ramps $30 \mathrm{~s}$ to $30 \mathrm{~s}$ at $14^{\circ} \mathrm{C}$ for $16 \mathrm{~h}$ in $0.5 \times$ TBE tank buffer $(45 \mathrm{mM}$ Tris-borate, 1 mM EDTA, pH 8.0). Following electrophoresis, nucleic acids were visualized by staining for $1 \mathrm{~h}$ with SYBR Gold (Molecular Probes).

The genome type was determined by a nuclease treatment test. Aliquots $(7 \mu \mathrm{l}$ each) of the purified genome suspensions were digested with RNase A (Nippon Gene) at $0.05 \mathrm{~g} \mathrm{hl}^{-1}$, DNase I (Promega) at $0.5 \mathrm{U} \mathrm{\mu l}^{-1}$ at $37^{\circ} \mathrm{C}$ for $1 \mathrm{~h}$, or with $\mathrm{S} 1$ nuclease (Takara Bio) at $0.7 \mathrm{U} \mathrm{\mu l}^{-1}$ at $23^{\circ} \mathrm{C}$ for $15 \mathrm{~min}$. The samples were then electrophoresed in 1\%(W/V) Agarose S gels (Nippon Gene). Nucleic acid extractions held on ice without enzymatic treatment served as controls. Nucleic acids were visualized by using ethidium bromide staining.

The purified virus suspension was mixed with onethird volume of $4 \times$ sample buffer $\left(62.5 \mathrm{mM}\right.$ Tris- $\mathrm{HCl}_{\text {, }}$ $5 \%$ 2-mercaptoethanol, $2 \%$ SDS, $20 \%$ glycerol and $0.005 \%$ bromophenol blue), boiled for 5 min and sonicated for $1 \mathrm{~min}$. The proteins were then separated by sodium dodecyl sulfate polyacrylamide gel electrophoresis (SDS-PAGE) $(80 \times 40 \times 1.0 \mathrm{~mm}, 12.5 \%$ gradient polyacrylamide gel, $150 \mathrm{~V}$ ) using an XV PANTERA SYSTEM (DRC). Proteins were visualized by Coomassie brilliant blue staining. Protein molecular weight standards (DRC) ranging from 6.5 to $200 \mathrm{kDa}$ were used for size calibration.

\section{RESULTS AND DISCUSSION}

\section{Virus isolation and its host range}

A pathogenic agent causing lysis of Sicyoidochytrium minutum strain NBRC 102975 was isolated from the surface water of the Shukugawa River estuary, Hyogo Prefecture, Japan. The pathogen was serially transferable to fresh host cultures, where more than $98 \%$ of host cells were lysed within $40 \mathrm{~h}$ post inoculation (Fig. 1).

By negative staining TEM, squashed ball-like VLPs were found in the lysate of NBRC 102975 culture inoculated with the pathogen (Fig. 2A). Although healthy cells of NBRC 102975 in the control cultures had cytoplasmic structures diagnostic of thraustochytrids, and showed no symptoms of viral infection (Fig. 2B), VLPs similar in size to those in the lysate were also observed in the cytoplasm of NBRC 102975 cells inoculated with the pathogen (Fig. 2C-E). These results demonstrate that (1) the pathogen was transferable to a fresh culture causing cell lysis, (2) the VLPs specifically appeared in lysed cultures, and (3) the 
Fig. 1. Optical photomicrographs of Sicyoidochytrium minutum strain NBRC 102975 (A) Intact cells; (B) lysed cells $48 \mathrm{~h}$ post inoculation with Sicyoidochytrium minutum DNA virus (SmDNAV)
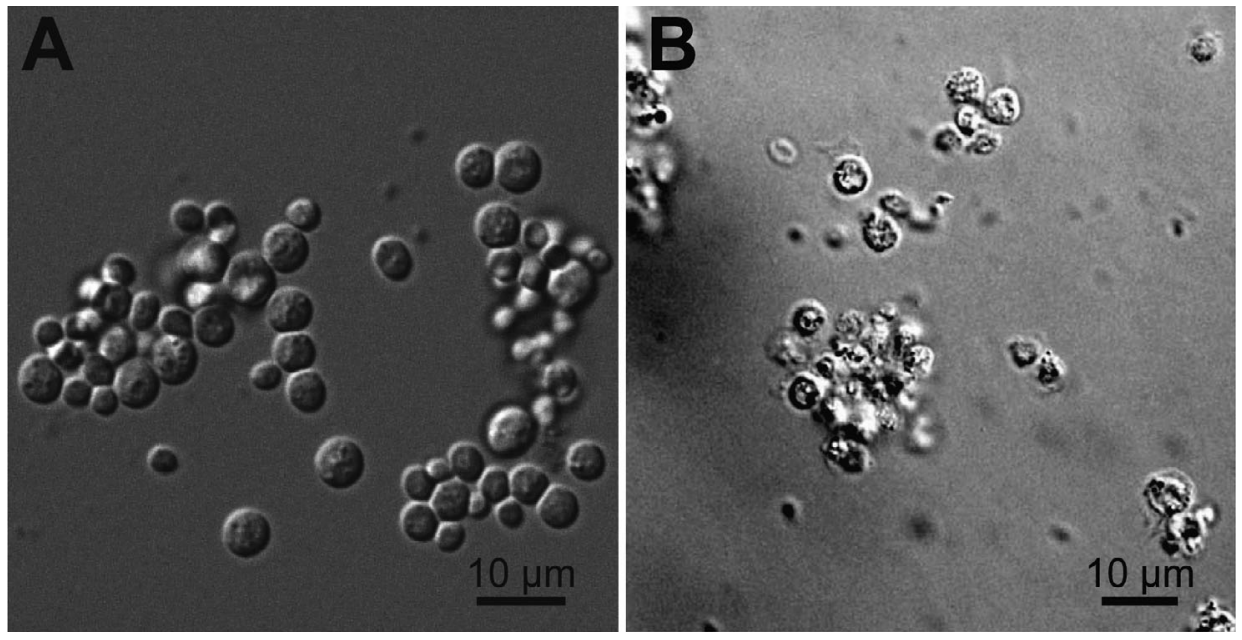

VLPs were not detected in healthy cultures, thus fulfilling Koch's postulates. Therefore, the VLP was revealed to be a virus infecting NBRC 102975. We have designated this virus SmDNAV (Sicyoidochytrium minutum DNA virus).

SmDNAV caused lysis of 2 Sicyoidochytrium minutum strains tested in this study (NBRC 102975 and SEK 0354) (Table 1) (Takao et al. 2005). By contrast, SmDNAV showed no effect on the other thraustochytrid strains including those sensitive to SssRNAV (Table 1) (Takao et al. 2005). SmDNAV infecting the S. minutum strain SEK 0354 was isolated from Malaysia. This suggests that the host-virus system is distributed over a wide geographic area (tropical and temperate seas).

Fig. 2. Transmission electron photomicrographs of Sicyoidochytrium minutum strain NBRC 102975 infected with SmDNAV. (A) Negatively stained SmDNAV particles in the culture lysate. (B) Thin section of a healthy cell of $S$. minutum strain NBRC 102975. N: nucleus; G: Golgi body; Mt: mitochondrion. (C) Thin section of a SmDNAV-infected cell at $24 \mathrm{~h}$ post inoculation (black arrowheads show intracellular virions; white arrowheads show extracellular virions). (D) Crystalline arrays of SmDNAV inside the cell. (E) Mature and immature virions (arrows show immature virions). (F) Virus particles along the damaged nucleus
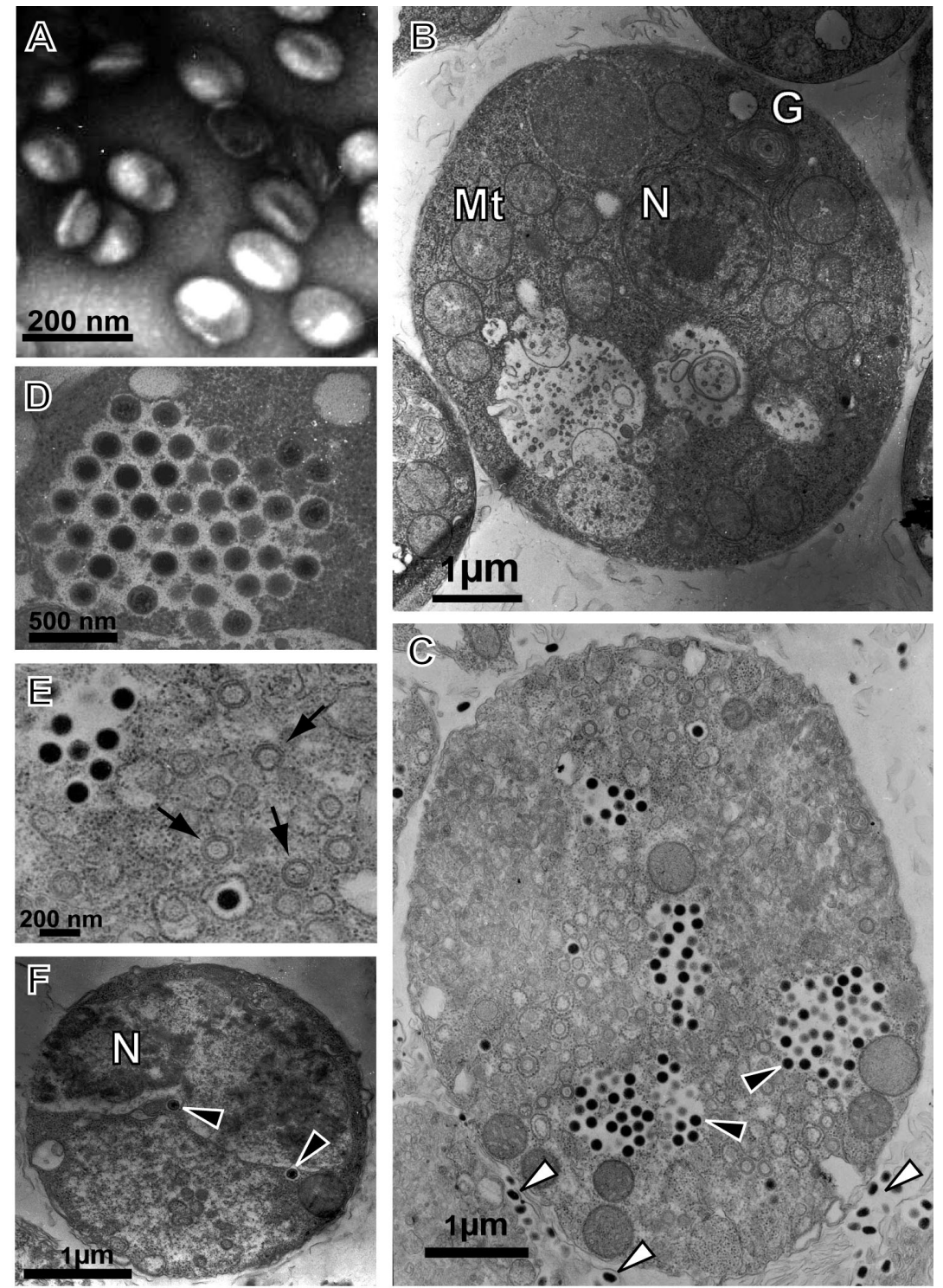


\section{TEM observations}

In the SmDNAV-infected cells, viral accumulation occurred in the cytoplasm, where the newly generated virions were roundish $(126 \pm 7 \mathrm{~nm}$ in diameter; average \pm standard deviation, $\mathrm{n}=30$ ) (Fig. 2C-E). They often formed crystalline arrays (Fig. 2D) or random aggregations (Fig. 2C) in host cytoplasm. Occasionally they coexisted with double-membraned VLPs (Fig. 2E), which may be immature virions. In addition, in the early stage of viral infection, virus particles were formed close to the damaged periphery of the nucleus (Fig. 2F), and nuclei were not found in cells whose cytoplasm was occupied with mature virions (data not shown). These data suggest that a great deal of nuclear damage is caused by SmDNAV-infection.

The virions released from the host cells looked elliptical in thin sections $(141 \pm 5 \mathrm{~nm}$ and $98 \pm 7 \mathrm{~nm} ; \mathrm{n}=$ 30) (Fig. 2C). The size is consistent with the negatively stained mature virions $(146 \pm 10 \mathrm{~nm}$ and $112 \pm 10 \mathrm{~nm}$; $\mathrm{n}=50$ ) (Fig. 2A). Hence, it was considered that once they were released into the ambient seawater environment (medium), the roundish virions changed their forms into the 'squashed ball-like' appearance. The squashed ball-like virions were occasionally observed in the mostly lysed cells (data not shown). The mechanism driving this remarkable morphological change has not been elucidated; differences in osmotic pressure between intracellular condition and ambient condition might be one of the causes.

The morphology of SmDNAV differs considerably from other viruses, e.g. icosahedral viruses (family Phycodnaviridae, Iridoviridae and Hypochytridialesinfecting virus) (Dawe \& Kuhn 1983, Chinchar et al. 2005, Wilson et al. 2005), non-icosahedral viruses (family Ascoviridae, Poxviridae) (Buller et al. 2005, Federici et al. 2005), and the herpes-type VLPs previously found in Thraustochytrium sp. (Kazama \& Schornstein 1973). The morphology of the family Fuselloviridae and the genus Salterprovirus looks similar to SmDNAV; however, these are infectious to prokaryotes and have a short tail (Bath \& Dyall-Smith 2005, Stedman 2005). Because of these observations, it is suggested that SmDNAV is distinct from any previously known dsDNA viruses.

\section{Replication of SmDNAV}

In the triplicate growth experiment, a rapid decrease in host cell abundance within $8 \mathrm{~h}$ post inoculation was accompanied by a rapid increase in viral titer (Fig. 3). Consequently, the latent period and the burst size of SmDNAV was estimated at 8 to $16 \mathrm{~h}$ and 3.6 to $10.6 \times$ $10^{2}$ infectious units cell ${ }^{-1}$. The latent period of SmD-

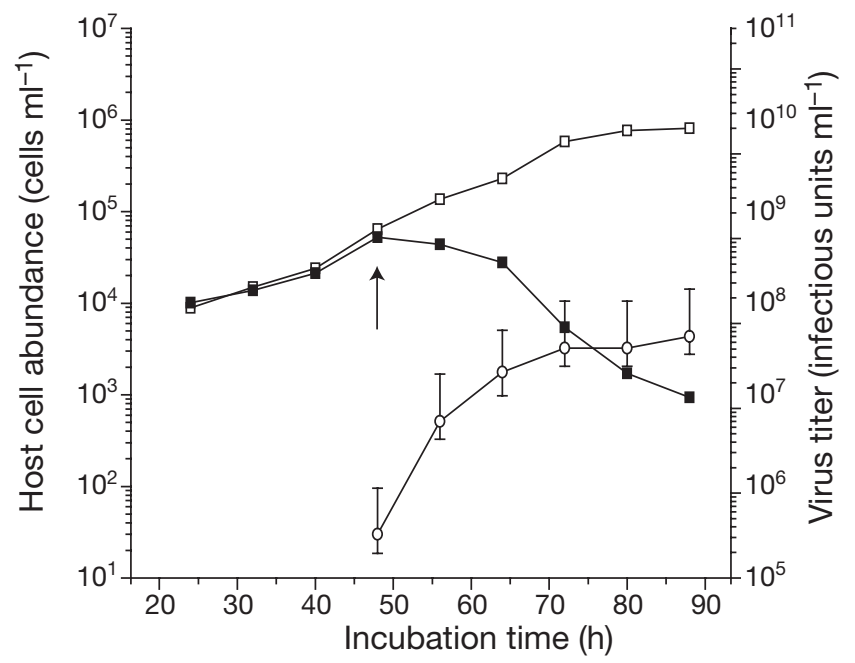

Fig. 3. Changes in abundance of Sicyoidochytrium minutum strain NBRC 102975 cells with (匹) or without () viral inoculation, and the viral titer (0). SmDNAV inoculation was performed in the exponentially growing phase of host cultures (arrow). Note that only results for one of the triplicate experiments are shown. Error bars indicate the 95\% confidence limits for viral titer

NAV is shorter than that of marine phycodnaviruses, which infect microalgae (Brussaard 2004), and compares with that of SssRNAV ( $<8 \mathrm{~h}$ ) (Takao et al. 2005). The burst size of SmDNAV is comparable to that of microalgal dsDNA viruses (Brussaard 2004), but is much less than that of SssRNAV $\left(5.8 \times 10^{3}\right.$ to $6.4 \times 10^{4}$ infectious units cell ${ }^{-1}$ ) (Takao et al. 2005). Besides, SmDNAV lost infectivity in the chloroform treatment (data not shown); this suggests that the virions have a lipid-containing component that is required for their infectivity.

\section{Genome and proteins of SmDNAV}

Nucleic acid purified from SmDNAV was sensitive to DNase I but resistant to RNase A and S1 nuclease (Fig. 4A), indicating that SmDNAV genome is a dsDNA. By PFGE, the SmDNAV genome was estimated to be $\sim 200 \mathrm{kbp}$ in length (Fig. 4B). This genome size is similar to that of other dsDNA viruses infecting eukaryotic algae (the family Phycodnaviridae) (Wilson et al. 2005, Claverie et al. 2006). By contrast, the genome sizes of the family Fuselloviridae (14.7 to $17.8 \mathrm{kbp}$ ) and the genus Salterprovirus (14.5 kbp) are much smaller than that of SmDNAV (Bath \& DyallSmith 2005, Stedman 2005).

The protein analysis showed that SmDNAV had one major protein of $20.5 \mathrm{kDa}$ in molecular weight; the second major band was $28 \mathrm{kDa}$; minor proteins of 86.5 , 56.5 and $40 \mathrm{kDa}$ were also observed. (Fig. 5). 

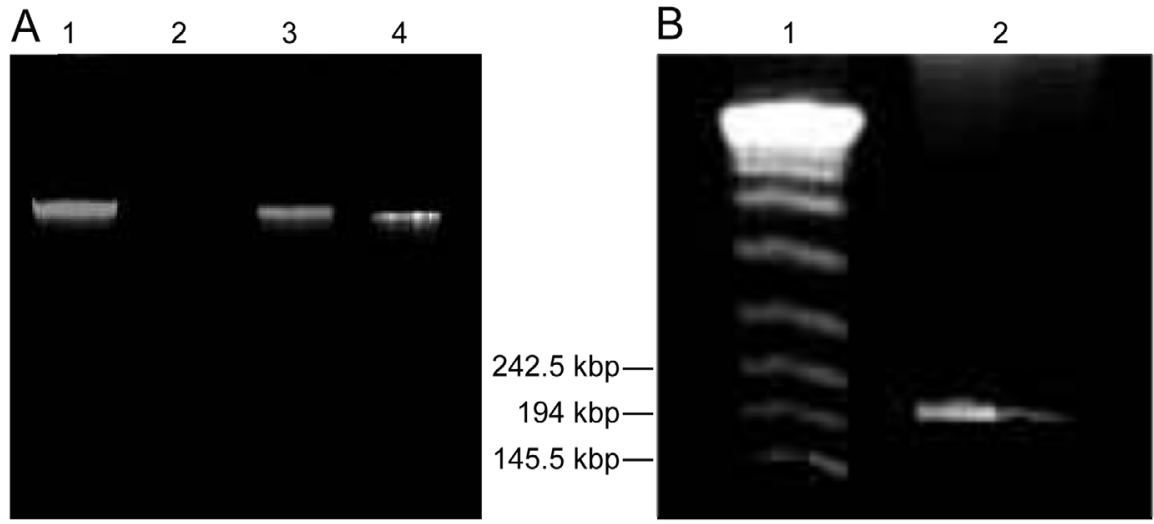

Fig. 4. Genome of Sicyoidochytrium minutum DNA virus (SmDNAV). (A) Nuclease treatment test. SmDNAV nucleic acids were untreated (Lane 1), treated with DNase I at $37^{\circ} \mathrm{C}$ (Lane 2), treated with RNase A at $37^{\circ} \mathrm{C}$ (Lane 3) and treated with S1 nuclease at $23^{\circ} \mathrm{C}$ (Lane 4). (B) Pulsed-field gel electrophoresis of viral nucleic acids (Lane 2); molecular marker is shown in Lane 1

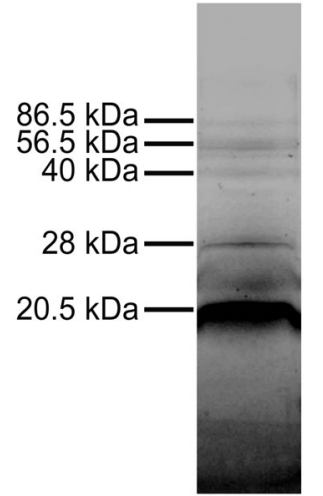

Fig. 5. Sodium dodecyl sulfatepolyacrylamide gel electrophoresis of Sicyoidochytrium minutum DNA virus (SmDNAV) structural proteins. The gel was stained with Coomassie brilliant blue

\section{Implications}

SmDNAV is a novel dsDNA virus which infects the marine fungoid protist Sicyoidochytrium minutum, strain NBRC 102975. The characteristics of SmDNAV are quite different from those of SssRNAV that infects Aurantiochytlium sp., herpes-type VLPs of Thraustochytrium sp. and any other previously known dsDNA viruses (Kazama \& Schornstein 1973, Takao et al. 2005). Although further genomic study is necessary to determine its taxonomic position, SmDNAV should be recognized as a member of the previously unknown viruses.

This is the second report of viruses infecting thraustochytrids that have been cultured. The difference in the phylogenetic position of host strains and replication ability of SmDNAV and SssRNAV are notable when considering their ecology. It indicates that at least 2 distinctive thraustochytrid-virus systems coexist in the coastal ecosystem. Further ecological study is required to reveal the relationships of these host-virus systems, and it should lead to further understanding of the detailed ecology of thraustochytrids.

Acknowledgements. This work was supported by the Kato Memorial Bioscience Foundation, the Asahi Glass Foundation, Fisheries Research Agency, Japan, and Grant-in-Aid for Scientific Research from the Japan Society for the Promotion of Science (JSPS) (No. 14255004). The authors are grateful to Dr. T. Nakahara, Dr. T. Yokochi (National Institute of Advanced Industrial Science and Technology, Japan), and Dr. R. Yokoyama (Konan University, Japan), who kindly provided the thraustochytrid strains. We thank Dr. Y. Tomaru (National Research Institute of Fisheries and Environment of Inland Sea, Fisheries Research Agency, Japan) for technical advice on transmission electron microscopy.

\section{LITERATURE CITED}

Bath C, Dyall-Smith ML (2005) Salterprovirus. In: Fauquet CM, Mayo MA, Maniloff J, Desselberger U, Ball LA (eds) Virus taxonomy, VIIIth report of the ICTV. Elsevier Academic Press, Chian, p 111-113

Brussaard CPD (2004) Viral control of phytoplankton populations - a review. J Eukaryot Microbiol 51:125-138

Buller RM, Arif BM, Black DN, Dumbell KR and others (2005) Poxviridae. In: Fauquet CM, Mayo MA, Maniloff J, Desselberger U, Ball LA (eds) Virus taxonomy, VIIIth report of the ICTV. Elsevier Academic Press, Chian, p $117-133$

Chen LCM, Edelstein T, McLachlan J (1969) Bonnemaisonia hamifera Hariot in nature and in culture. J Phycol 5: 211-220

Chinchar VG, Essbauer S, He JG, Hyatte A, Miyazaki T, Seligy V, Williams T (2005) Iridoviridae. In: Fauquet CM, Mayo MA, Maniloff J, Desselberger U, Ball LA (eds) Virus taxonomy, VIIIth report of the ICTV. Elsevier Academic Press, Chian, p 145-162

Claverie JM, Ogata H, Audic S, Abergel C, Suhre K, Fournier PE (2006) Mimivirus and the emerging concept of 'giant' virus. Virus Res 117:133-144

Dawe VH, Kuhn CW (1983) Isolation and characterization of a double-stranded DNA mycovirus infecting the aquatic fungus, Rhizidiomyces. Virology 130:21-28

Federici BA, Bigot Y, Granados RR, Hamm JJ and others (2005) Ascoviridae. In: Fauquet CM, Mayo MA, Maniloff J, Desselberger U, Ball LA (eds) Virus taxonomy, VIIIth report of the ICTV. Elsevier Academic Press, Chian, p 269-274

Fuhrman JA (1999) Marine viruses and their biogeochemical and ecological effects. Nature 399:541-548

Garza DR, Suttle CA (1995) Large double-stranded DNA viruses which cause the lysis of a marine heterotrophic nanoflagellate (Bodo sp.) occur in natural marine viral communities. Aquat Microb Ecol 9:203-210

Honda D, Yokochi T, Nakahara T, Raghukumar S, Nakagiri A, Schaumann K, Higashihara T (1999) Molecular phylogeny of labyrinthulids and thraustochytrids based on 
the sequence of $18 \mathrm{~S}$ ribosomal RNA gene. J Eukaryot Microbiol 46:637-647

Imai I, Itoh K (1987) Raphidophyceae. In: Association Jfrc (ed) A guide for studies of red tide organisms. Shuwa, Tokyo, p 122-130

Iyer LM, Balaji S, Koonin EV, Aravind L (2006) Evolutionary genomics of nucleo-cytoplasmic large DNA viruses. Virus Res 117:156-184

Kazama FY, Schornstein KL (1973) Ultra-structure of a fungus herpes-type virus. Virology 52:478-487

Kimura H, Fukuba T, Naganuma T (1999) Biomass of thraustochytrid protoctists in coastal water. Mar Ecol Prog Ser 189:27-33

Naganuma T, Takasugi H, Kimura H (1998) Abundance of thraustochytrids in coastal plankton. Mar Ecol Prog Ser 162:105-110

Nagasaki K, Ando M, Imai I, Itakura S, Ishida Y (1993) Viruslike particles in an apochlorotic flaellate in Hiroshima Bay, Japan. Mar Ecol Prog Ser 96:307-310

Nagasaki K, Ando M, Imai I, Itakura S, Ishida Y (1995) Viruslike particles in unicellular apochlorotic microorganisms in the coastal water of Japan. Fish Sci 61:235-239

Nakahara T, Yokochi T, Higashihara T, Tanaka S, Yaguchi T, Honda D (1996) Production of docosahexaenoic and docosapentaenoic acid by Schizochytrium sp. isolated from Yap Islands. J Am Oil Chem Soc 73:1421-1426

Nishihara T, Kurano N, Shinoda S (1986) Calculation of most probable number for enumeration of bacteria on microcomputer. Eisei Kagaku 32:226-228 (in Japanese with English abstract)

Polglase JL (1980) A preliminary report on the thraustochytrid(s) and labyrinthurid(s) associated with a pathological condition in lesser octopus Eledone cirrhosa. Bot Mar 23:699-706

Porter D (1989) Phylum Labyrinthulomycota. In: Margulis L, Corliss JO, Melkonian M, Chapman D (eds) Handbook of Protoctista. Jones \& Bartlett, Boston, MA, p 388-398

Proctor LM, Fuhrman JA (1990) Viral mortality of marine bacteria and cyanobacteria. Nature 343:60-62

Ragan MA, MacCallum GS, Murphy CA, Cannone JJ, Gutell RR, McGladdery SE (2000) Protistan parasite QPX of hardshell clam Mercenaria mercenaria is a member of Labyrinthulomycota. Dis Aquat Org 42:185-190

Editorial responsibility: Gunnar Bratbak, Bergen, Norway
Raghukumar S (2002) Ecology of the marine protists, the Labyrinthulomycetes (thraustochytrids and labyrinthulids). Eur J Protistol 38:127-145

Raoult D, Audic S, Robert C, Abergel C and others (2004) The 1.2-megabase genome sequence of Mimivirus. Science 306:1344-1350

Stedman K (2005) Fuselloviridae. In: Fauquet CM, Mayo MA, Maniloff J, Desselberger U, Ball LA (eds) Virus taxonomy, VIIIth report of the ICTV. Elsevier Academic Press, Chian, p $107-110$

Suttle CA (1993) Enumeration and isolation of viruses. In: Kemp PF, Sherr B, Sherr E, Cole JJ (eds) Handbook of methods in aquatic microbial ecology. Lewis Publishers, Boca Raton, FL, p 121-137

Takao Y, Nagasaki K, Mise K, Okuno T, Honda D (2005) Isolation and characterization of a novel single-stranded RNA virus infectious to a marine fungoid protist, Schizochytrium sp. (Thraustochytriaceae, Labyrinthulea). Appl Environ Microbiol 71:4516-4522

Takao Y, Mise K, Nagasaki K, Okuno T, Honda D (2006) Complete nucleotide sequence and genome organization of a single-stranded RNA virus (SssRNAV) infecting the marine fungoid Schizochytrium sp. J Gen Virol 87:723-733

Wilhelm SW, Suttle CA (1999) Viruses and nutrient cycles in the sea. Biosci Biotechnol Biochem 49:781-788

Wilson WH, Van Etten JL, Schroeder DC, Nagasaki K and others (2005) Phycodnaviridae. In: Fauquet CM, Mayo MA, Maniloff J, Desselberger U, Ball LA (eds) Virus taxonomy, VIIIth report of the ICTV. Elsevier Academic Press, Chian, p 163-175

Yokoyama R, Honda D (2007) Taxonomic rearrangement of the genus Schizochytrium sensu lato based on morphology, chemotaxonomical characteristics, and 18S rRNA gene phylogeny (Thraustochytriaceae, Labyrinthulomycetes): emendation for Schizochytrium and erection of Aurantiochytrium and Oblongichytrium gen. nov. Mycoscience 48:199-211

Yokoyama R, Salleh B, Honda D (2007) Taxonomic rearrangement of the genus Ulkenia sensu lato phylogeny based on morphology, chemotaxonomical characteristics and 18S rRNA gene (Thraustochytriaceae, Labyrinthulomycetes): emendation for Ulkenia and erection of Botryochytrium, Parietichytrium and Sicyoidochytrium gen. nov. Mycoscience 48:329-341

Submitted: June 1, 2007; Accepted: August 29, 2007 Proofs received from author(s): October 29, 2007 